\title{
IMPLEMENTASI SISTEM INFORMASI DATA SIMPAN PINJAM BERBASIS SMS GATEWAY PADA DINAS PEKERJAAN UMUM PENATAAN RUANG DAN PERTANAHAN KABUPATEN TANAH LAUT
}

\author{
Dwi Retnosari ${ }^{1)}$, Auliya Rahman ${ }^{2)}$ \\ ${ }^{1)}$ Fakultas Teknologi Informasi, Universitas Islam Kalimantan Muhammad Arsyad Al Banjari \\ ${ }^{2)}$ Fakultas Teknologi Informasi, Universitas Islam Kalimantan Muhammad Arsyad Al Banjari \\ ${ }^{1)}$ Email :dwiretnosarisari@gmail.com \\ ${ }^{2)}$ Email :auliyarahmankom@gmail.com
}

\begin{abstract}
Abstrak
Koperasi pada Dinas Pekerjaan Umum Penataan Ruang dan Pertanahan Kabupaten Tanah Laut adalah salah satu badan usaha yang bergerak dibidang simpan pinjam yang melayani anggota khususnya dalam bidang pelayanan simpan pinjam, saat ini pengelolaan data simpan pinjam masih dilakukan secara semi manual yaitu dengan menggunakan aplikasi microsoft word dan kemudian dibukukan secara manual, hal tersebut kurang efektif dan kurang effisien karena membutuhkan waktu yang cukup lama pada saat proses pencarian data simpan pinjam, selain itu pada saat melakukan transaksi simpan pinjam kepada anggota juga harus membutuhkan waktu yang cukup lama dan sering terjadi kekeliruan dalam pengolahan datanya sehingga memperlambat dalam proses pelayanan terhadap anggota koperasi sehingga diperlukan suatu aplikasi yang lebih efekif dan efisien dalam mengelola data simpan pinjam di koperasi Dinas Pekerjaan Umum Penataan Ruang dan Pertanahan Kabupaten Tanah Laut. Guna meningkatkan pelayanan dan pengelolaan data koperasi yang lebih cepat dan akurat pada Dinas Pekerjaan Umum Penataan Ruang dan Pertanahan Kabupaten Tanah Laut maka perlu dibuat suatu Implementasi Sistem Informasi simpan pinjam Berbasis SMS Gateway. Dalam pembuatan aplikasi ini, menggunakan bahasa pemograman Borland Delphi 7.0. Pada aplikasi ini juga terdapat menu sms gateway yang bertujuan untuk memudahkan petugas dalam mengirimkan informasi melalui sms secara langsung kepada banyak anggotanya sehingga diharapkan aplikasi koperasi simpan pinjam ini dapat digunakan lebih tepat, cepat dan hasil yang lebih akurat.
\end{abstract}

Kata Kunci : Sistem Informasi, Simpan Pinjam, Delphi7

\section{PENDAHULUAN}

Koperasi Simpan Pinjam adalah suatu koperasi yang kegiatan usahanya menghimpun dan menyalurkan dana kepada para anggotanya dengan bunga yang rendah. Tujuan koperasi ini adalah untuk meningkatkan kesejahteraan para anggotanya. Dengan kata lain, tujuan utama koperasi bukanlah untuk memperoleh laba tapi manfaatnya bagi para anggota.

Menurut Undang-Undang Nomor 25 Tahun 1992 Pasal 3 tujuan koperasi Indonesia adalah untuk memajukan kesejahteraan anggota pada khususnya dan masyarakat pada umumnya serta ikut membangun tatanan perekonomian nasional dalam rangka mewujudkan masyarakat yang maju, adil dan makmur berlandaskan Pancasila dan Undang-Undang Dasar 1945.

Dengan semakin banyaknya jumlah anggota dan semakin berkembangnya teknologi, maka sudah saatnya memanfaatkan kemajuan teknologi informasi yang ada yaitu sistem komputerisasi, Jurnal Ilmiah "Technologia" sehingga proses pengelolaan data simpan pinjam bisa dilakukan lebih transparan, akurat serta dapat dipertanggungjawabkan secara lebih baik kepada anggotanya.

Koperasi pada Dinas Pekerjaan Umum Penataan Ruang dan Pertanahan Kabupaten Tanah Laut adalah salah satu badan usaha yang bergerak dibidang simpan pinjam yang melayani anggota khususnya dalam bidang pelayanan simpan pinjam, saat ini pengelolaan data simpan pinjam masih dilakukan secara semi manual yaitu dengan menggunakan aplikasi microsoft word dan kemudian dibukukan secara manual, hal tersebut kurang efektif dan kurang effisien karena membutuhkan waktu yang cukup lama pada saat proses pencarian data simpan pinjam, selain itu pada saat melakukan transaksi simpan pinjam kepada anggota juga harus membutuhkan waktu yang cukup lama dan sering terjadi kekeliruan dalam pengolahan datanya sehingga memperlambat dalam proses pelayanan terhadap 
anggota koperasi, dari permasalahan diatas maka diperlukan suatu aplikasi yang lebih efekif dan efisien dalam mengelola data simpan pinjam di koperasi Dinas Pekerjaan Umum Penataan Ruang dan Pertanahan Kabupaten Tanah Laut.

Pada tahap awal pendirian koperasi di Dinas Pekerjaan Umum Penataan Ruang dan Pertanahan Kabupaten Tanah Laut dimana jumlah anggota koperasi dan transaksi keuangan masih sedikit, pengelolaan keuangan koperasi mungkin tidak terlalu menjadi masalah, karena masih dapat dilakukan secara manual dan masih mudah untuk ditelusuri. Namun seiring dengan perjalananannya, dimana jumlah anggota dan jumlah transaksi keuangan semakin banyak, pengelolaan keuangan koperasi akan bertambah kompleks dan menyulitkan, sehingga akhirnya banyak pekerjaan atau proses akuntansi yang terbengkalai. Pada tahap ini, dukungan alat seperti menambahan aplikasi sudah mulai dibutuhkan untuk mengelola data simpan pinjam dengan baik. Melihat dari masalah yang ada, maka perlu dibuat suatu "Implementasi Sistem Informasi Data Simpan Pinjam Berbasis Sms Gateway Pada Dinas Perkerjaan Umum Penataan Ruang Dan pertanahan Kabupaten Tanah Laut " yang dapat membantu untuk meningkatkan pelayanan anggotanya serta terintegrasinya semua transaksi keuangan dalam satu sistem sehingga memudahkan pengurus untuk melakukan pemantauan dan pengawasan transaksi yang dijalankan.

\section{METODE PENELITIAN}

Metode penelitian yang digunakan dalam pembuatan aplikasi ini terdiri dari beberapa langkah, yaitu :

a. Analisis Kebutuhan (Requirement Analisis). Pengembangan system untuk memahami perangkat lunak yang diharapkan pengguna dan disesuaikan dengan kebutuhan dalam pembuatan sistem simpan pinjam. Analisis kebutuhan ini dengan melakukan dialog (tanya jawab) secara langsung dengan petugas di kantor dinas Pekerjaan Umum Penataan Ruang dan Pertanahan Kabupaten Tanah Laut dalam memberikan keterangan terhadap data yang dibutuhkan dalam sistem simpan pinjam.

b. Sistem Desain (Design System), Menentukan perangkat keras (hardware) dan perangkat lunak (software) untuk mendefinisikan arsitektur dalam sistem simpan pinjam. Perancangan sistem simpan pinjam tersebut meliputi:

\section{1.) Arsitektur Model Sistem}

Untuk mengatasi permasalahan yang terjadi pada sistem yang dijalankan saat ini, maka dibentuk sebuah sistem yang tentunya memiliki keunggulan, sistem tersebut. Digambarkan dengan diagram. Dengan diagram ini diharapkan akan mempermudah pemahaman terhadap hasil analisa, sehingga apabila terjadi kesalahan dapat diketahui sedini mungkin.

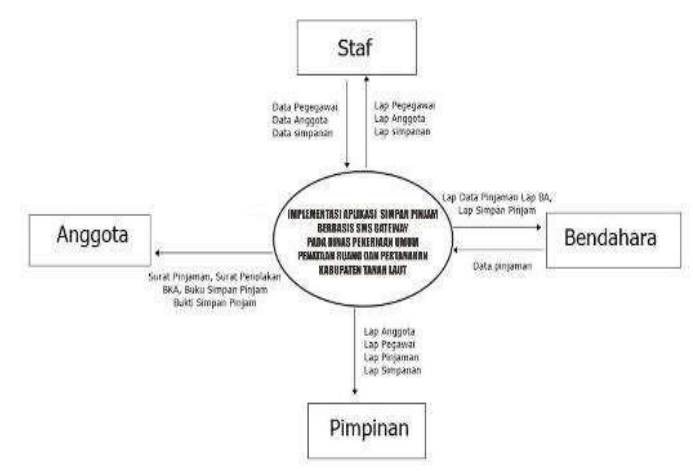

Gambar 2.1 Diagram Konteks

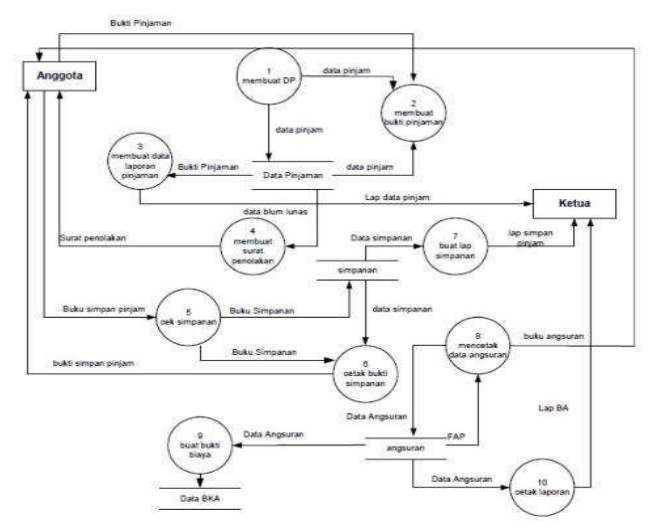

Gambar 2.2 Rancangan Data Flow Diagram level 1

\section{2). Rancangan Database}

a. Tabel Login

Tabel 1. Tabel login

\begin{tabular}{|c|c|c|c|}
\hline Field Name & Type & Size & Keterangan \\
\hline Username & Text & 8 & Username \\
\hline Password & Text & 6 & Password \\
\hline
\end{tabular}

b. Tabel Anggota 
Tabel 2. Tabel Anggota

\begin{tabular}{|c|c|c|c|}
\hline Field Name & Type & Size & Keterangan \\
\hline No_anggota & Varchar & 14 & $\begin{array}{c}\text { Nomor } \\
\text { Anggota }\end{array}$ \\
\hline $\begin{array}{c}\text { Nama_anggot } \\
\text { a }\end{array}$ & Varchar & 30 & $\begin{array}{c}\text { Nama } \\
\text { Anggota }\end{array}$ \\
\hline Tempat_lahir & Varchar & 30 & Tempat Lahir \\
\hline Tanggal_lahir & Varchar & 14 & Tanggal Lahir \\
\hline Jenis_kelamin & Varchar & 14 & Jenis Kelamin \\
\hline Agama & Varchar & 20 & Agama \\
\hline Alamat & Varchar & 35 & Alamat \\
\hline Tgl_masuk & Varchar & 14 & $\begin{array}{c}\text { Tanggal } \\
\text { Masuk }\end{array}$ \\
\hline Status & Varchar & 20 & Status \\
\hline Unit_kerja & Varchar & 30 & Unit Kerja \\
\hline
\end{tabular}

c. Tabel Simpanan

Tabel 3. Tabel Simpanan

\begin{tabular}{|c|c|c|c|}
\hline Field Name & Type & Size & Keterangan \\
\hline No_simpanan & Varchar & 6 & $\begin{array}{c}\text { Nomer } \\
\text { Simpanan }\end{array}$ \\
\hline No_anggota & Varchar & 8 & $\begin{array}{c}\text { Nomer } \\
\text { Anggota }\end{array}$ \\
\hline $\begin{array}{c}\text { Nama_anggot } \\
\text { a }\end{array}$ & Varchar & 30 & $\begin{array}{c}\text { Nama } \\
\text { Anggota }\end{array}$ \\
\hline Bulan & Varchar & 14 & $\begin{array}{c}\text { Besar } \\
\text { Simpanan }\end{array}$ \\
\hline $\begin{array}{c}\text { Besar_simpan } \\
\text { an }\end{array}$ & Varchar & 20 & Keterangan \\
\hline Keterangan & Varchar & 35 & Keterangan \\
\hline Sisa & Varchar & 20 & Sisa saldo \\
\hline
\end{tabular}

\section{d. Tabel Penarikan}

Tabel 4. Tabel Penarikan

\begin{tabular}{|c|c|c|c|}
\hline Field Name & Type & Size & Keterangan \\
\hline No_penarikan & $\begin{array}{c}\text { Varcha } \\
\text { r }\end{array}$ & 14 & $\begin{array}{c}\text { Nomor } \\
\text { penarikan }\end{array}$ \\
\hline No_anggota & $\begin{array}{c}\text { Varcha } \\
\text { r }\end{array}$ & 10 & $\begin{array}{c}\text { Nomor } \\
\text { anggota }\end{array}$ \\
\hline Nama_Anggota & $\begin{array}{c}\text { Varcha } \\
\text { r }\end{array}$ & 25 & $\begin{array}{c}\text { Nama } \\
\text { anggota }\end{array}$ \\
\hline No_simpanan & $\begin{array}{c}\text { Varcha } \\
\text { r }\end{array}$ & 14 & No simpanan \\
\hline
\end{tabular}

\begin{tabular}{|c|c|c|c|}
\hline $\begin{array}{c}\text { Besar_penarika } \\
\mathrm{n}\end{array}$ & $\begin{array}{c}\text { Varcha } \\
\mathrm{r}\end{array}$ & 20 & $\begin{array}{c}\text { Besar } \\
\text { penarikan }\end{array}$ \\
\hline Tanggal & $\begin{array}{c}\text { Varcha } \\
\mathrm{r}\end{array}$ & 14 & Tanggal \\
\hline Keterangan & $\begin{array}{c}\text { Varcha } \\
\mathrm{r}\end{array}$ & 20 & Keterangan \\
\hline Besar_simpanan & $\begin{array}{c}\text { Varcha } \\
\mathrm{r}\end{array}$ & 20 & $\begin{array}{c}\text { Besar } \\
\text { simpanan }\end{array}$ \\
\hline Sisa_simpanan & $\begin{array}{c}\text { Varcha } \\
\mathrm{r}\end{array}$ & 20 & Sisa simpanan \\
\hline
\end{tabular}

e. Tabel Angsuran

Tabel 5. Tabel Angsuran

\begin{tabular}{|c|c|c|c|}
\hline Field Name & Type & Size & Keterangan \\
\hline No_angsuran & $\begin{array}{c}\text { Varcha } \\
\text { r }\end{array}$ & 14 & $\begin{array}{c}\text { Nomor } \\
\text { angsuran }\end{array}$ \\
\hline No_pinjaman & $\begin{array}{c}\text { Varcha } \\
\text { r }\end{array}$ & 14 & $\begin{array}{c}\text { No } \\
\text { pinjaman }\end{array}$ \\
\hline No_anggota & $\begin{array}{c}\text { Varcha } \\
\text { r }\end{array}$ & 14 & $\begin{array}{c}\text { Nomor } \\
\text { anggota }\end{array}$ \\
\hline Nama_anggota & $\begin{array}{c}\text { Varcha } \\
\text { r }\end{array}$ & 25 & $\begin{array}{c}\text { Nama } \\
\text { anggota }\end{array}$ \\
\hline Tanggal_angsuran & $\begin{array}{c}\text { Varcha } \\
\text { r }\end{array}$ & 25 & $\begin{array}{c}\text { Tanggal } \\
\text { angsuran }\end{array}$ \\
\hline Nominal & $\begin{array}{c}\text { Varcha } \\
\text { r }\end{array}$ & 25 & Nominal \\
\hline Batas_pembayaran & $\begin{array}{c}\text { Varcha } \\
\text { r }\end{array}$ & 25 & $\begin{array}{c}\text { Batas } \\
\text { pembayaran }\end{array}$ \\
\hline Angsuran_ke & $\begin{array}{c}\text { Varcha } \\
\text { r }\end{array}$ & 14 & Angsuran ke \\
\hline Keterangan & $\begin{array}{c}\text { Varcha } \\
\text { r }\end{array}$ & 35 & Keterangan \\
\hline
\end{tabular}

f. Tabel Pegawai

Tabel 6.Tabel Pegawai

\begin{tabular}{|c|c|c|c|}
\hline Field Name & Type & Size & Keterangan \\
\hline Id_pegawai & Varchar & 20 & ID Pegawai \\
\hline Nama_pegawai & Varchar & 25 & $\begin{array}{c}\text { Nama } \\
\text { Pegawai }\end{array}$ \\
\hline Nip & Varchar & 25 & Nip \\
\hline Tempat_lahir & Varchar & 25 & $\begin{array}{c}\text { Tempat } \\
\text { Lahir }\end{array}$ \\
\hline Tanggal_lahir & Varchar & 15 & $\begin{array}{c}\text { Tanggal } \\
\text { Lahir }\end{array}$ \\
\hline Jenis_kelamin & Varchar & 15 & $\begin{array}{c}\text { Jenis } \\
\text { Kelamin }\end{array}$ \\
\hline
\end{tabular}




\begin{tabular}{|l|l|l|l|}
\hline Agama & Varchar & 15 & Agama \\
\hline Jabatan & Varchar & 20 & Jabatan \\
\hline Alamat & Varchar & 30 & Alamat \\
\hline
\end{tabular}

g. Tabel Pinjaman

Tabel 7. Tabel Pinjaman

\begin{tabular}{|c|c|c|c|}
\hline Field Name & Type & Size & $\begin{array}{c}\text { Keteranga } \\
\text { n }\end{array}$ \\
\hline No_pinjaman & Varchar & 14 & $\begin{array}{c}\text { Nomer } \\
\text { Pinjaman }\end{array}$ \\
\hline No_anggota & Varchar & 14 & $\begin{array}{c}\text { Nomer } \\
\text { Anggota }\end{array}$ \\
\hline Nama_anggota & Varchar & 20 & $\begin{array}{c}\text { Besar } \\
\text { Pinjaman }\end{array}$ \\
\hline Besar_pinjaman & Varchar & 25 & $\begin{array}{c}\text { Jangka } \\
\text { Waktu } \\
\text { Pinjaman }\end{array}$ \\
\hline Jangka_waktu & Varchar & 20 & Angsuran \\
\hline Bunga & Varchar & 20 & Bunga \\
\hline Angsuran & Varchar & 25 & Angsuran \\
\hline Jumlah & Varchar & 32 & Jumlah \\
\hline
\end{tabular}

\section{3) Relasi Antar Tabel}

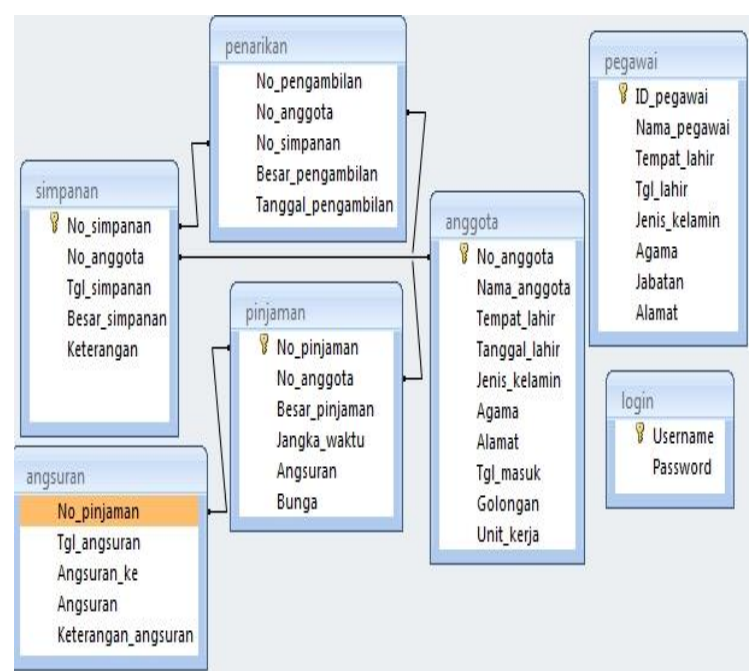

Gambar 2. 1 Relasi Antar Tabel

\section{c. Pelaksanaan (Implementation)}

Mengimplementasikan Sistem Informasi simpan pinjam berbasis sms Gateway

\section{d. Integrasi dan Pengujian Sistem (Integration and Testing)}

Seluruh unit yang dikembangkan dalam tahap implementasi diintegrasikan ke dalam Sistem Informasi.

\section{e. Maintanance}

Pemeliharaan termasuk dalam memperbaiki kesalahan yang tidak ditemukan pada langkah sebelumnya .

\section{HASIL DAN PEMBAHASAN}

1. Login

Tampilan Login sebelum masuk ke Menu Utama Implementasi Sistem Informasi Data Simpan Pinjam Berbasis Sms Gateway Pada Dinas Perkerjaan Umum Penataan Ruang dan Pertanahan Kabupaten Tanah Laut, tampilan dari awal login adalah sebagai berikut :

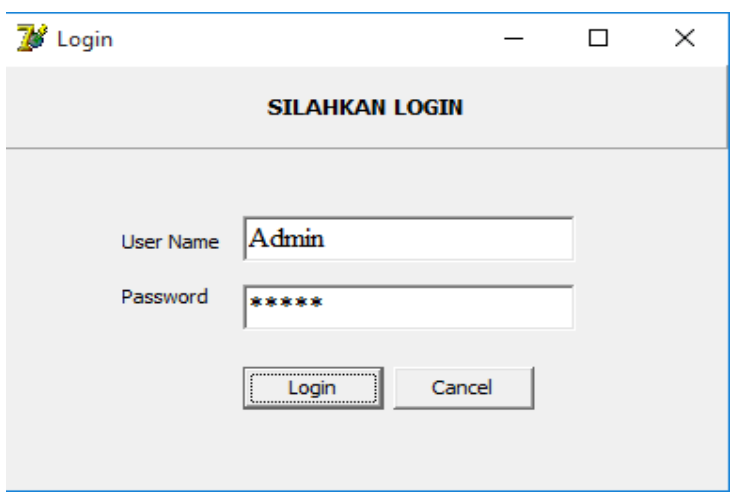

Gambar 1. Form Login

\section{Halaman Menu Utama}

Bagian awal dari program ini adalah menu utama dari Implementasi Sistem Informasi Data Simpan Pinjam yang akan masuk ke menu-menu atau form-form selanjutnya. Dari halaman utama program ini kita bisa langsung memilih menu apa yang akan kita buka sesuai kebutuhan. Halaman menu utama ini menampilkan beberapa sub menu, pada sub menu file terdapat pilhan data pegawai, data anggota, data simpanan, dan data pinjaman, pada sub menu transaksi terdapat pilihan data angsuran, data penarikan dana, dan data sms gateaway, pada sub menu laporan terdapat pilihan menu laporan pegawai, laporan anggota, laporan simpanan, laporan pinjaman, laporan angsuran, laporan penarikan dana, tampilan dari menu utama adalah sebagai berikut: 


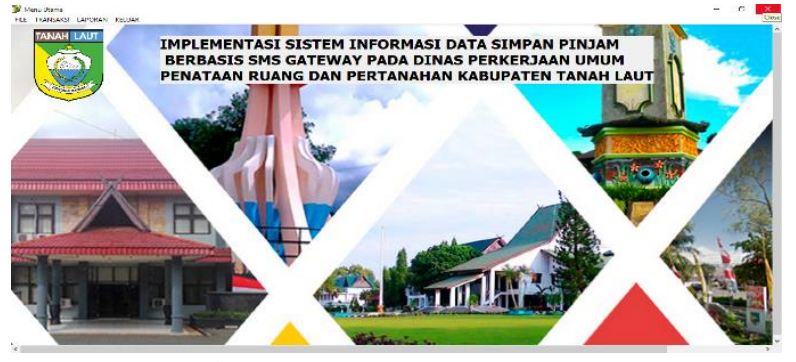

Gambar 2. From Menu Utama

\section{Halaman Form Data Pegawai}

Pada form data pegawai terdapat 9 field inputan untuk memasukan data melalui program sesuai dengan struktur pada table di database nya. Dan dilengkapi dengan tombol baru, simpan, edit, hapus dan keluar.

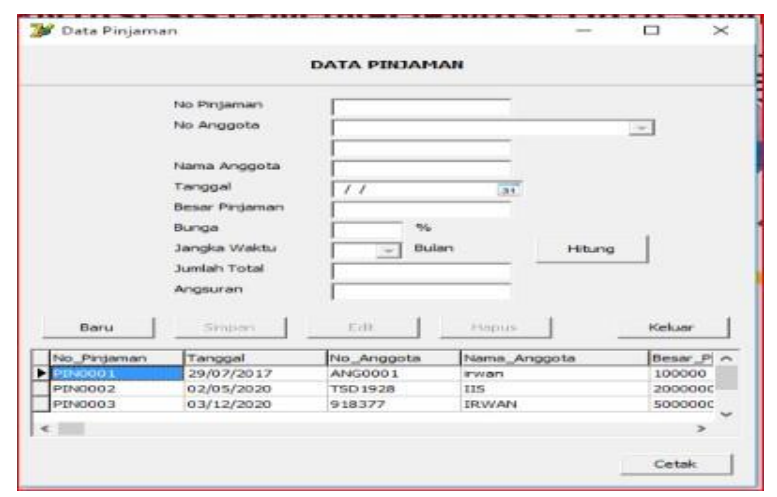

Gambar 3. Form Data Pegawai

\section{Halaman Form Data Anggota}

Anggota Pada form data anggota terdapat 11 field inputan untuk memasukan data melalui program sesuai dengan struktur pada table di database nya dan dilengkapi dengan tombol baru, simpan, edit, hapus dan keluar.

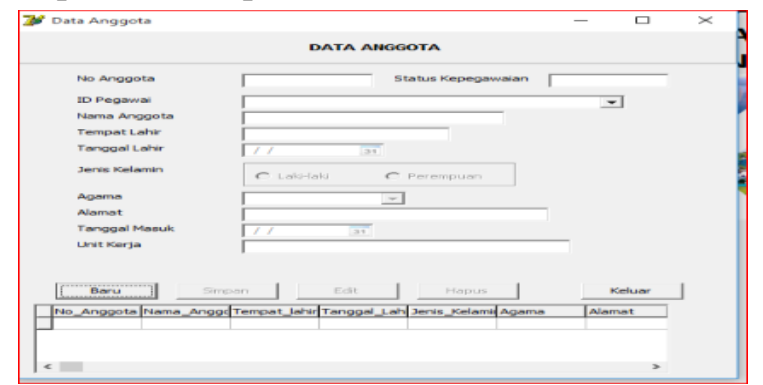

Gambar 4. Form Data Anggota

\section{Halaman Form Data Simpanan}

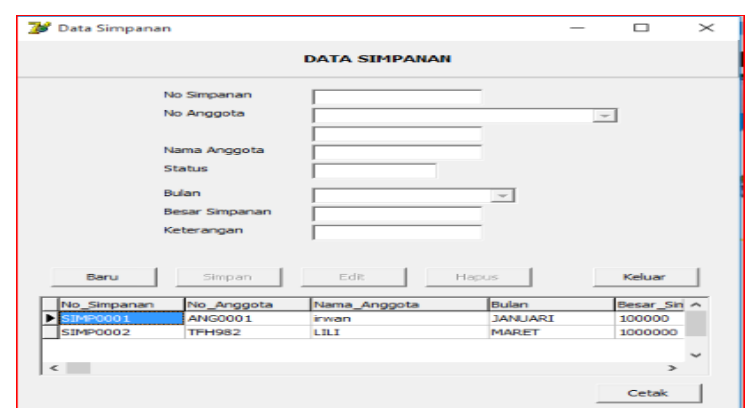

Gambar 5. Data Simpanan

\section{Halaman Form Data Pinjaman}

Data pinjaman terdapat 10 field inputan untuk memasukan data melalui program sesuai dengan struktur pada table di database nya. Dan dilengkapi dengan tombol hitung, baru, simpan, edit, hapus dan keluar.

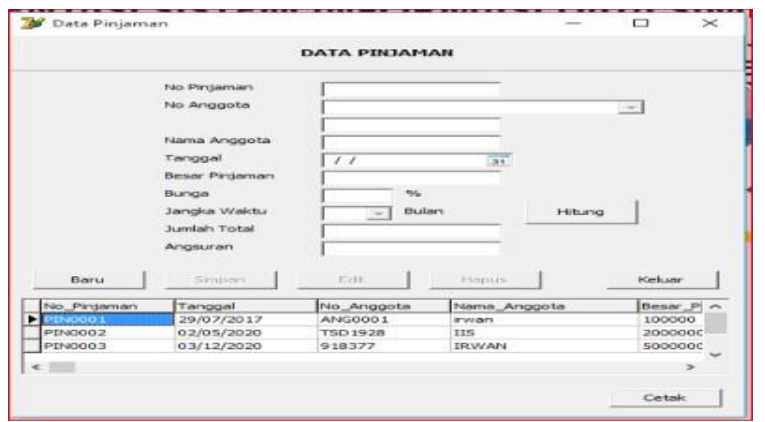

Gambar 6. Form Data Pinjaman

\section{Halaman Form Data Angsuran}

Pada form data angsuran terdapat 11 field inputan untuk memasukan data melalui program sesuai dengan struktur pada table di database nya. Dan dilengkapi dengan tombol hitung, baru, simpan, edit, hapus dan keluar.

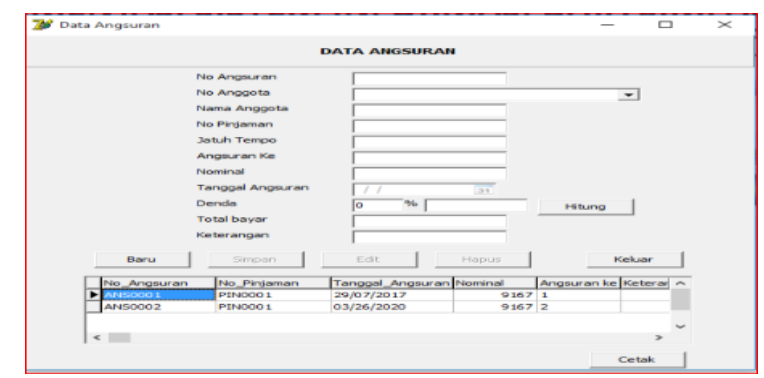

Gambar 7. Form Data Angsuran 


\section{Halaman Form Data Penarikan Dana}

Pada form data penarikan dana terdapat 10 field inputan untuk memasukan data melalui program sesuai dengan struktur pada table di database nya lalu dilengkapi dengan tombol hitung, baru, simpan, edit, hapus dan keluar.

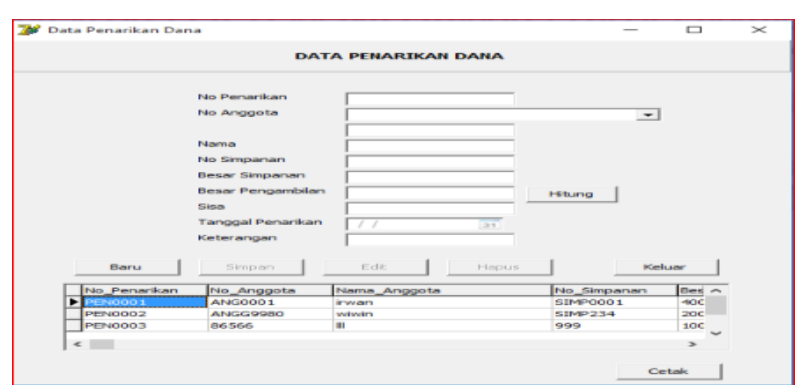

Gambar 8. Form Data Penarikan Dana

\section{Form SMS Geteway}

Pada form sms gateway terdapat 4 field inputan untuk memasukan data melalui program sesuai dengan struktur pada table di database nya. Dan dilengkapi dengan tombol Tampilkan, Close, Kirim, Cancel dan Simpan.

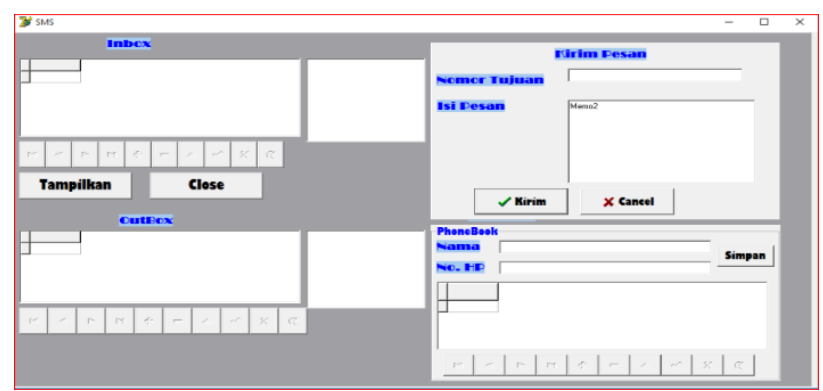

Gambar 9. Form Sms Geteway

10. Halaman Form Print Data Simpanan

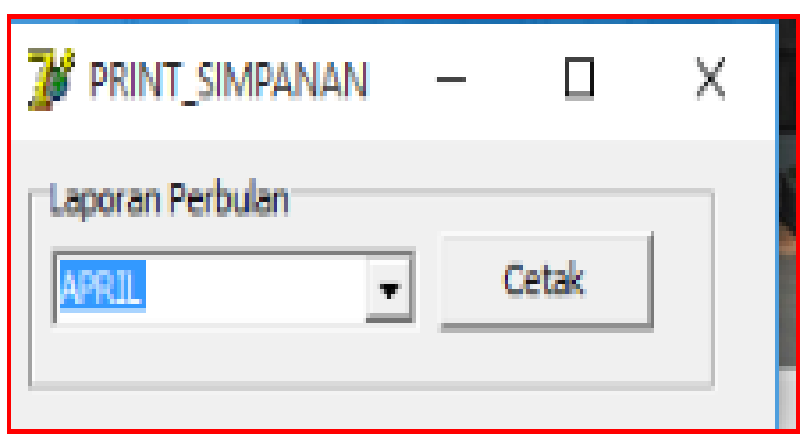

Gambar 10. Form Print Data Simpanan

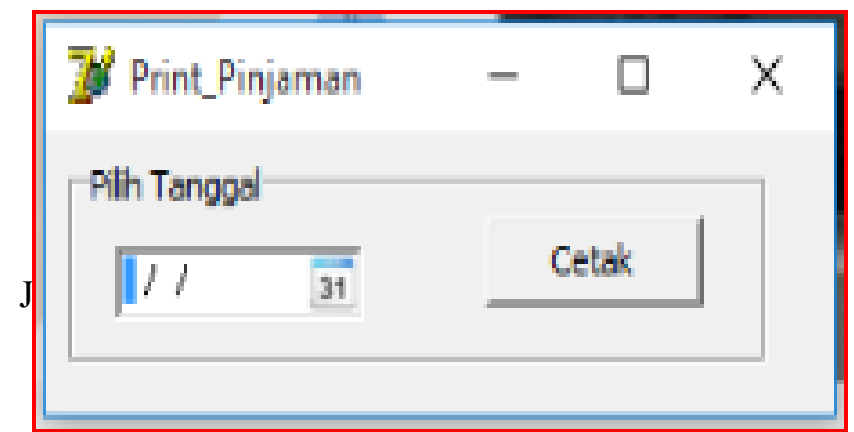

11. Halaman Form Print Data Pinjaman

Gambar 11. Form Print Data Pinjaman

\section{Halaman Form Print Data Angsuran}

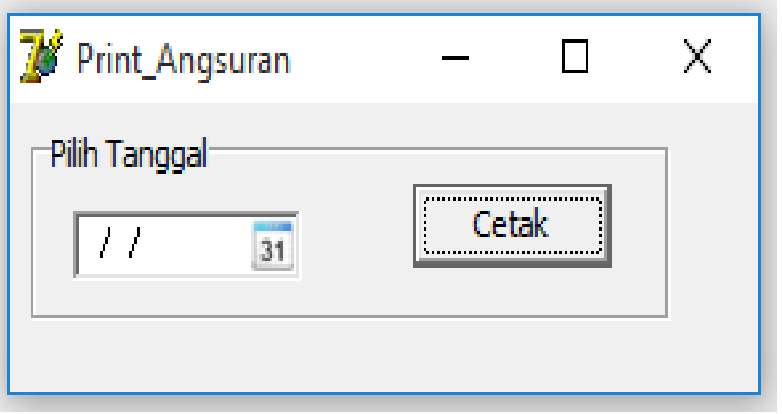

Gambar 12. Form Print Data Angsuran

\section{Halaman Form Print Data Penarikan}

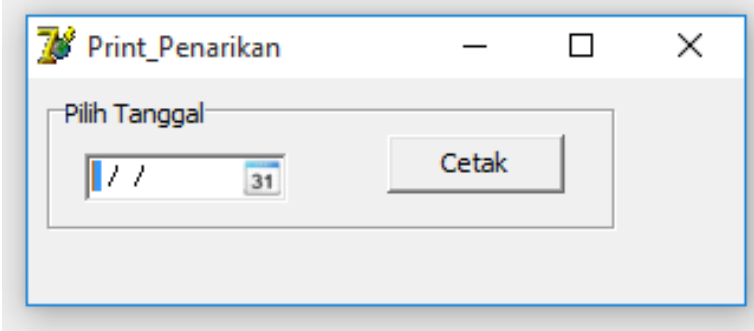

Gambar 13. Form Print Data Angsuran

\section{Halaman Form Print Ulang Transaksi \\ Angsuran}

Pada form ini terdapat 10 field inputan yang terdiri dari No Angsuran, No Pinjaman, Tanggal Angsuran, Nominal, Angsuran Ke, Keterangan, No Anggota, Nama Anggota, Denda, Total

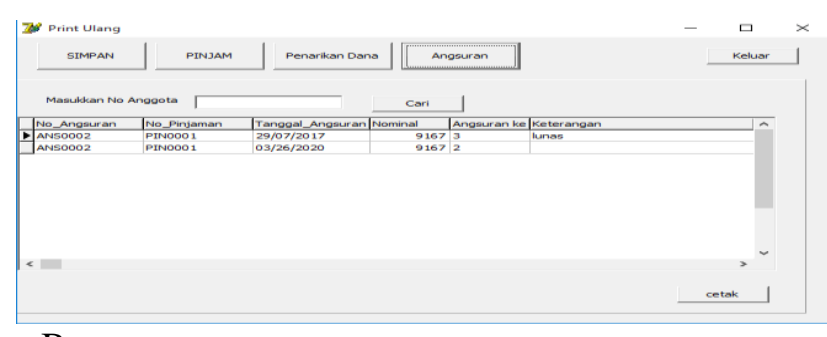

Bayar.

Gambar 14. Form Print Ulang Transaksi Angsuran 15. Halaman Form Print Ulang Penarikan Dana

Form ini memiliki 9 field inputan yang terdiri dari No Penarikan, No Anggota, Nama Anggota, No Simpanan, Besar Penarikan, Tanggal,

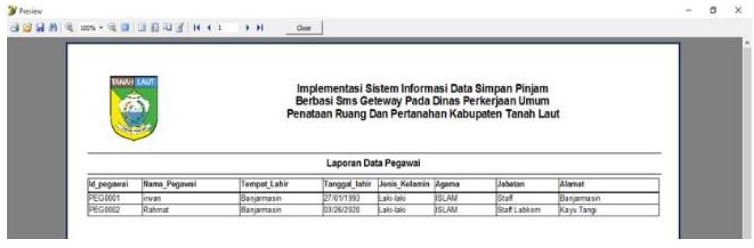


Keterangan, Besar Simpanan, dan Sisa.

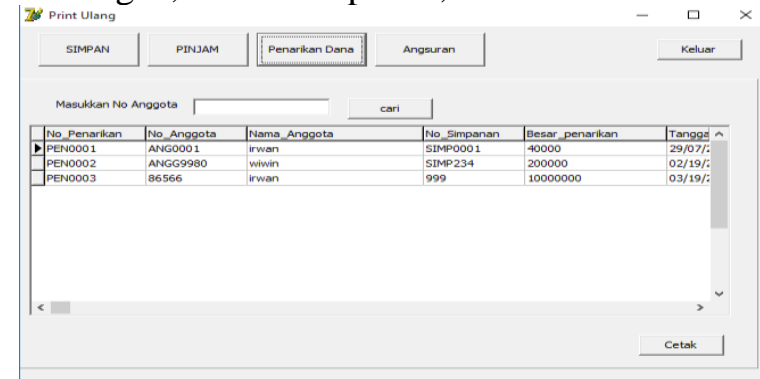

Gambar 15. Halaman Form Print Ulang Penarikan Dana

\section{Halaman Form Print Ulang Pinjaman}

Pada form ini terdapat 8 field inputan yang terdiri dari No Pinjaman, Tanggal, No Anggota, Nama Anggota, Besar Penarikan, Jangka Waktu, Bunga, Angsuran, dan Jumlah.

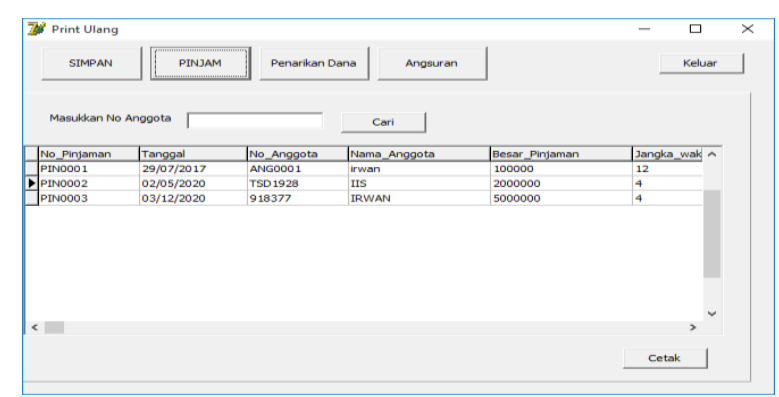

Gambar 16. Halaman Form Print Ulang Pinjaman

\section{Halaman Form Print Ulang Simpanan}

Pada form ini terdapat 7 field inputan yang terdiri dari No Simpanan, No Anggota, Nama Anggota, Bulan, Besar Simpanan, Keterangan, dan Sisa.

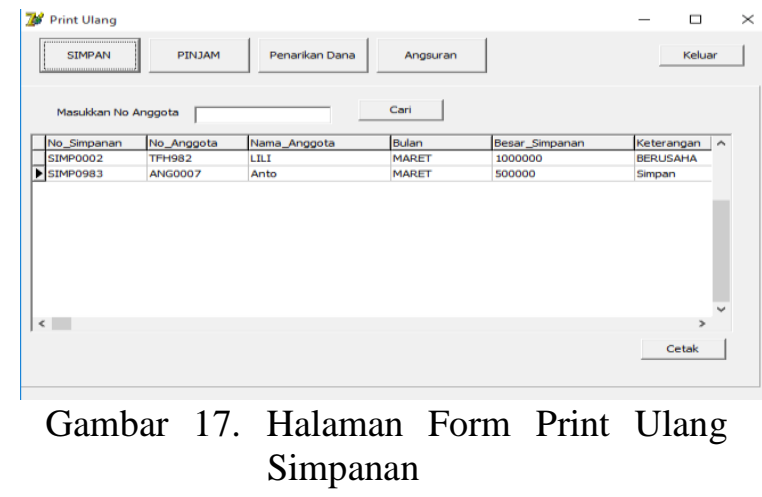

\section{Halaman Cetak Laporan Data Pegawai}

Berikut isi dari halaman cetak Laporan ata Pegawai yang mana terdiri dari laporan Pegawai, Nama Pegawai, Tempat Lahir, Jenis Kelamin,
Jabatan, dan Alamat.

$$
\text { Gambar 18. Form Laporan Data Pegawai }
$$

\section{Halaman Cetak Laporan Data Anggota}

Dari halaman cetak Laporan Data Anggota terdiri dari laporan No Anggota, Nama Anggota, Tempat Lahir, Tanggal Lahir, Jenis Kelamin, Agama, Alamat, Tanggal Masuk, Status dan Unit Kerja.

Gambar 19. Form Laporan Data Anggota

\section{Halaman Cetak Rekap Data Simpanan}

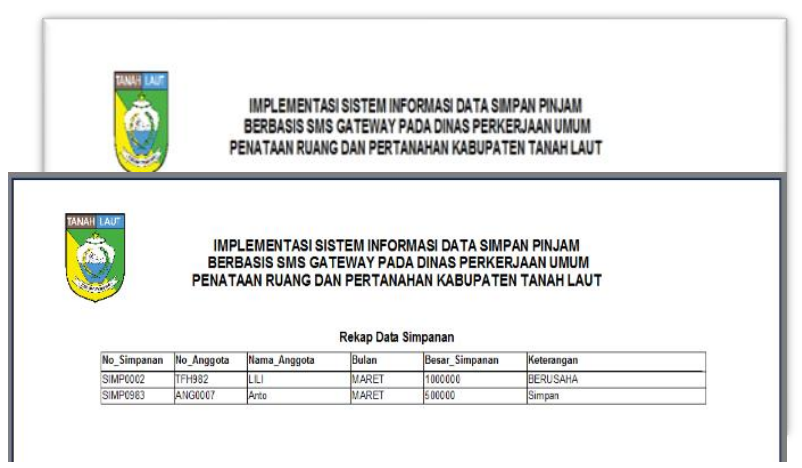

Dari halaman cetak Laporan Data Simpanan yang terdiri dari laporan No Simpanan, No Anggota, Nama Anggota, Bulan, Besar Simpanan, dan Keterangan.

Gambar 20. Form Rekap Data Simpanan

\section{Halaman Cetak Rekap Data Pinjaman}

Dari halaman cetak Laporan Data Pinjaman terdiri dari laporan No Pinjaman, Tanggal, No Anggota, Besar Simpanan, Jangka Waktu, Bunga, Angsuran, dan Jumlah.

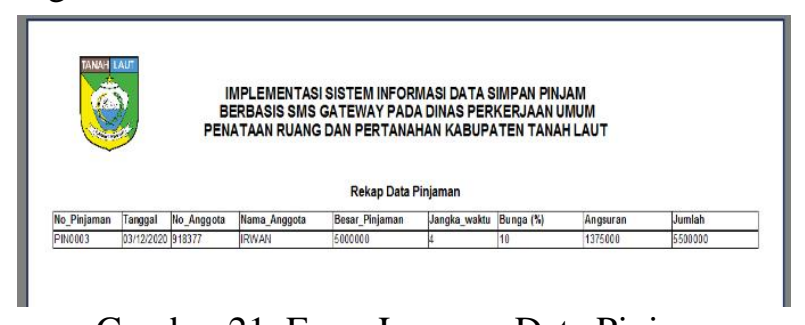

Gambar 21. Form Laporan Data Pinjaman

\section{Halaman Cetak Rekap Laporan Data Angsuran}


Beralih ke halaman cetak Laporan Data Angsuran yang mana terdiri dari laporan No Angsuran, No Pinjaman, No Anggota, Nama Anggota, Tanggal Angsuran, Nominal, Angsuran Ke, dan Keterangan.

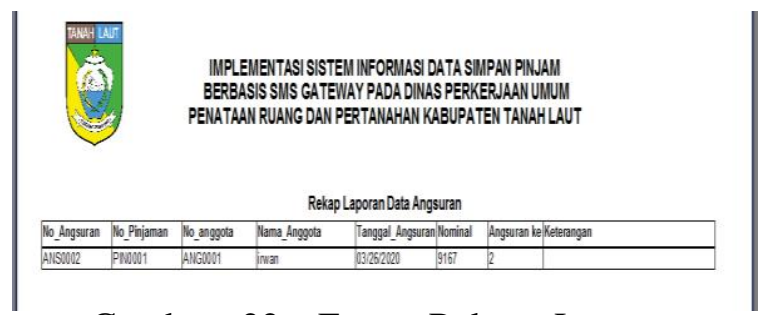

Gambar 22. Form Rekap Laporan Data Angsuran

\section{Halaman Cetak Rekap Laporan Penarikan}

Berikutnya adalah halaman cetak Laporan Data Penarikan yang mana terdiri dari laporan No Penarikan, No Pinjaman, No Anggota, Nama Anggota, No Simpanan, Besar Penarikan, Tanggal, Keterangan, Besar Simpanan, Sisa.

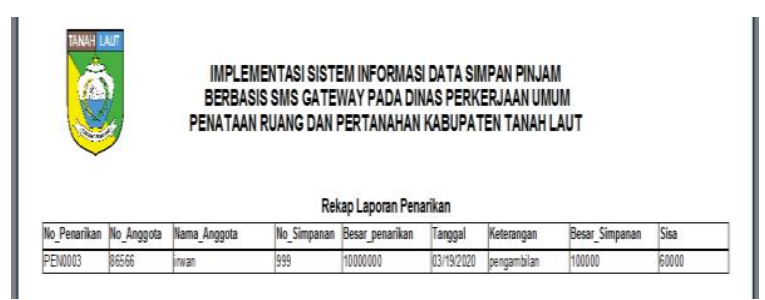

Gambar 23. Form Rekap Laporan Data Penarikan

24. Halaman Cetak Laporan Print Ulang Angsuran Pinjaman

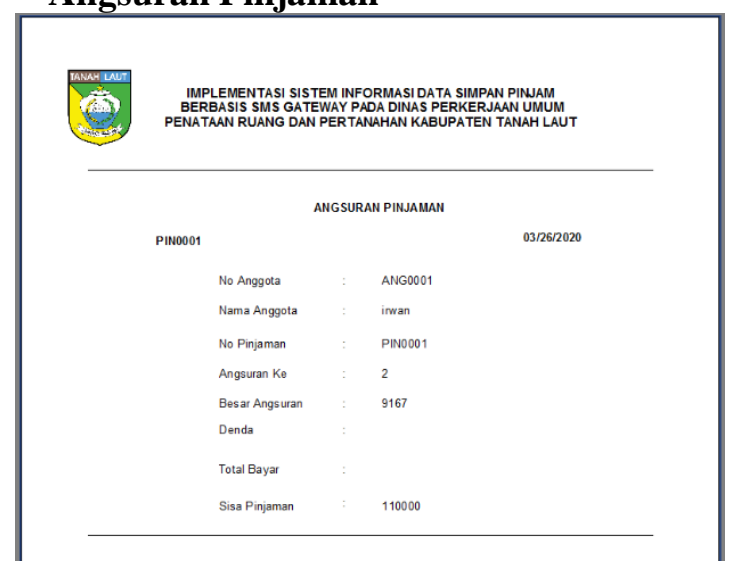

Gambar 24. Form Laporan Print Ulang Angsuran Pinjaman

\section{Halaman Cetak Laporan Print Ulang} Penarikan Dana

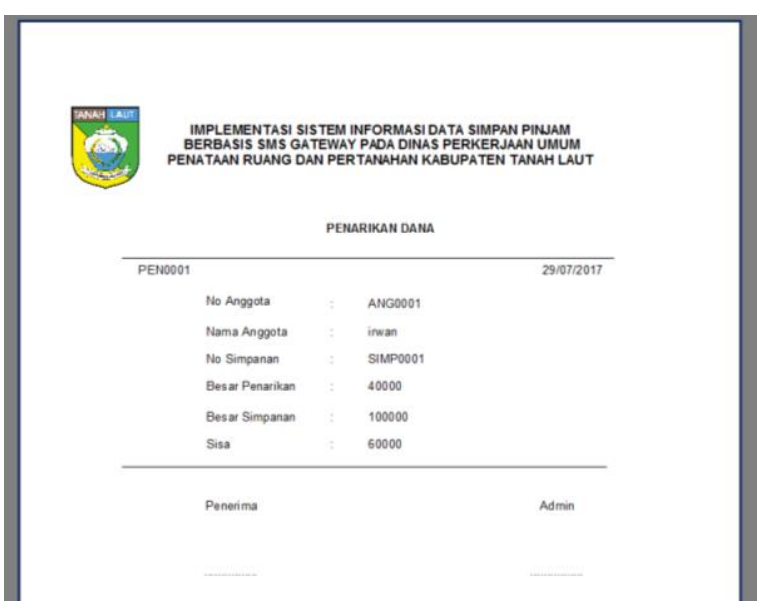

Gambar 25. Form Laporan Print Ulang Penarikan Dana

\section{Halaman Cetak Laporan Print Ulang Pinjaman Dana}

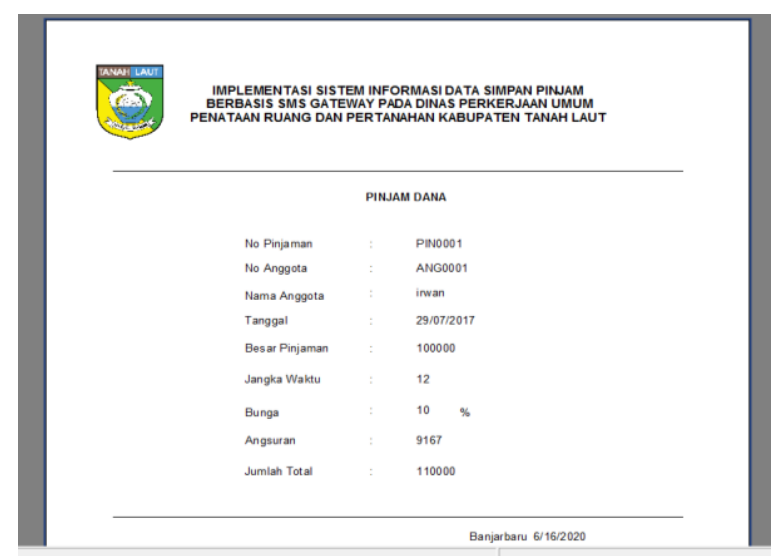


Gambar 26. Form Laporan Print Ulang Pinjaman Dana

\section{Halaman Cetak Laporan Print Ulang Simpanan Dana}

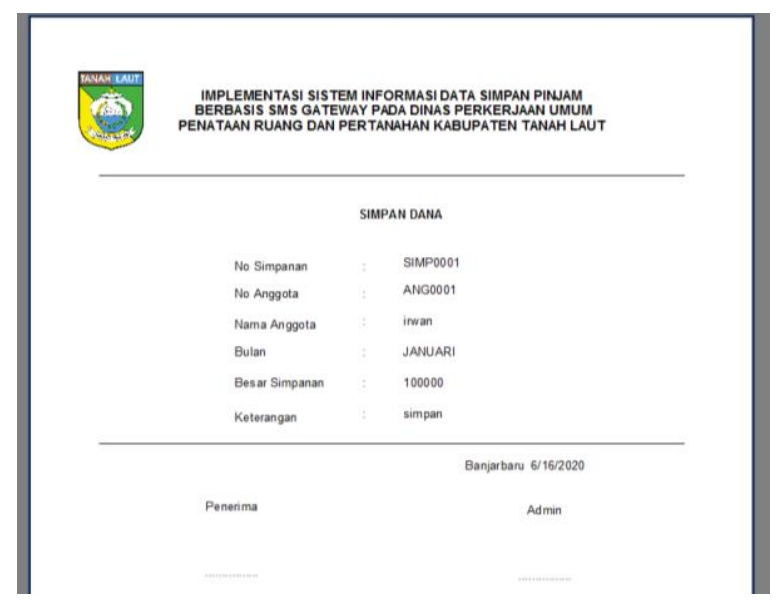

Gambar 27. Form Laporan Print Ulang Simpanan Dana perubahan (update) data secara cepat pada saat dibutuhkan.

\section{REFERENSI}

Hengky W. Pramana, (2012). Aplikasi Inventory Berbasis Access 2003.PT. Elex Media Komputindo, Jakarta.

Budi Sutedjo Dharma Oetomo, S. M. (2002). Perencaan dan Pengembangan Sistem Informasi. Yogyakarta: ANDI.

Perekonomian Indonesia. Jakarta: Rineka Cipta.

Kani., Firmansyah., \& Sufandi, Unggul Utan 2010, PEMROGRAMAN DATABASEMENGGUNAKAN DELPHI Delphi Win32 dan MySQL 5.0 dengan optimalisasi komponen ZeosDBO, Graha Ilmu, Yogyakarta.

Gunawan Ferry, "Membuat Aplikasi SMS Gateway dan Client dengan Java danPHP", PT Elex Media Komputindo, Jakarta,2003.

Jogiyanto, \& Hartono. (2009). Analisis \& Desain Sistem Informasi. Yogyakart: Andi Ofset.

Kristanto, A. (2008). Perancangan Sistem Informasi dan Aplikasinya. Yogyakarta: Gava Media.

\section{KESIMPULAN}

Berdasarkan hasil dari penelitian dan pembahasan diatas, dapat ditarik beberapa kesimpulan sebagai berikut :

1. Melalui aplikasi yang telah dibuat maka dapat membantu Petugas dalam mengelola data simpan pinjam dengan lebih mudah, efektif dan effisien serta menghasilkan data yang akurat

2. Dengan adanya aplikasi simpan pinjam dapat meningkatkan efisiensi kerja petugas atau pegawai yang berwenang dalam menggunakan program tersebut, dalam hal ini petugas juga dapat dapat melakukan 